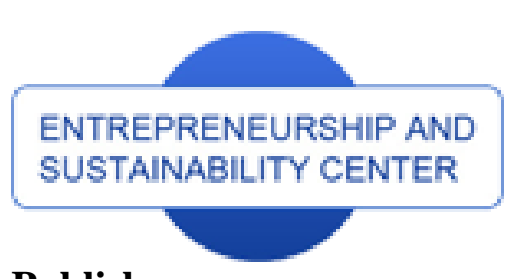

Publisher

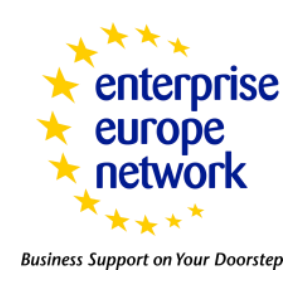

THOMSON REUTERS

Emerging Sources Citation Index WEB OF SCIENCE'M

\title{
DIVERSITY OF EMPLOYEE INCENTIVES FROM THE PERSPECTIVE OF BANKS EMPLOYEES IN POLAND - EMPIRICAL APPROACH*
}

\author{
Vladimir Aleksandrovich Davydenko ${ }^{1}$, Jerzy Kaźmierczyk ${ }^{2}$, \\ Gulnara Fatykhovna Romashkina ${ }^{3}$, Elżbieta Żelichowska ${ }^{4}$ \\ ${ }^{2,4}$ Poznan University of Economics and Business, address: al. Niepodległości 10, 61-875 Poznań, Poland \\ 1,2,3 Tyumen State University, address: 6 Volodarskogo St., 625003 Tyumen, Russia \\ E-mails: ${ }^{1}$ vlad_davidenko@mail.ru; ${ }^{2}$ jerzy.kazmierczyk@ue.poznan.pl; ${ }^{3}$ g.f.romashkina@utmn.ru; \\ ${ }^{4}$ zelichowska.e@gmail.com
}

Received 15 March 2017; accepted 26 June 2017

\begin{abstract}
This paper examines the diversity of employee incentives from the perspective of banks employees in Poland. According to the theory, employee motivation is a very significant factor which leads to the success of the entire organization and it is closely related to the motivation system in a workplace. It is important to underline the fact that motivation system is not always well-chosen which means that it is also not efficient in each organization. What is more, it is possible to observe differentiation in used motivation incentives in banks among different groups of employees. The purpose of this study was to investigate this segmentation according to the type of bank, gender and job position. Firstly, grounded in the literature, this article explains the importance of employee motivation tools. The research among bank employees let to verify propounded in this article theses. The results revealed the diversity in using employee incentives in banks in Poland. Furthermore, showed that commercial banks use more diverse employee incentives than cooperative ones, female employees in banks are motivated less diversely than males and managerial staff are motivated more diversely than employees in non-managerial positions.
\end{abstract}

Keywords: HRM, motivation, incentives, employee, banks, Poland

Reference to this paper should be made as follows: Davydenko, V.A., Kaźmierczyk, J., Romashkina, G.F., Żelichowska, E., 2017. Diversity of employee incentives from the perspective of banks employees in Poland - empirical approach, Entrepreneurship and Sustainability Issues, Entrepreneurship and Sustainability Issues 5(1): 116-126. http://doi.org/10.9770/jesi.2017.5.1(9)

JEL Classifications: J2, M5, M54

\section{Introduction}

According to M.W. Kopertynska, '...those who do not understand what motivates a good employee will sooner or later lose him. It is, therefore, worth learning what factors influence subordinates' motivation' (Kopertyńska 2009, p. 64). There is increasing awareness among employers and managers of the close relationship between their

\footnotetext{
* The study was sponsored by RGNF (Russian Humanitarian Science Foundation). Project: "Capabilities and Restrictions New Industrialization and Contradictions Sociocultural Space: on Tyumen Region Example", No. 16-03-00500. Tyumen State University
} 
employees' motivation and the results of the entire organization. It also affects the atmosphere in the workplace and relationships between employees. There are a lot of incentive tools available and many diverse people's needs.

In this paper are analyzed employee incentives in banks in Poland. From many sectors which have a big impact on the Polish economy, the banking sector has been chosen to be analyzed as the one which has been causing its dynamic growth. As one of the characteristics of this sector can be mentioned its complexity. Banks employ a variety of staff. Banks employees occupy many different positions associated with diverse tasks. The banking sector in the world is also a subject to a number of dynamic changes. Many solutions used in foreign banks is implemented in Poland. Also, those related to human resource management. As the motivation has been considered as an important issue not for a very long time, there are not so many studies on incentives used in banks.

Employee incentives are being assessed by many researchers (Abernethy, Dekker and Schulz 2015, p. 633; Barska and Łychmus 2007, pp. 39-40; Davydenko 2004, pp. 88-90; Drake, Wong and Salter 2007, p. 71; Andrianova and Davydenko 2011, pp. 96-98; Erbas and Erbas 2004, p. 91; Andrianova and Romashkina 2011, pp. 104-105; Fulghieri and Sevilir 2011, p. 2207; Park, Appelbaum and Kruse 2010, p. 227; Rehu, Lusk and Wolff 2005, p. 81; Andrianova, Davydenko and Romashkina 2011; Wang and Lim 2008, p. 701; Wang and Barney 2006, p. 466; Rosha, Lace 2015; Kaźmierczyk, Aptacy, 2016; Korauš et al. 2017; Ngo, Nguyen, 2016; Burianová, Paulík, 2014). Motivation is also of interest to practice (Cal-Chrobak and Kaźmierczyk 2017, p. 299; Chernomorchenko 2016, pp. 54-56; Dirzytė et al. 2016; Starineca, Voronchuk 2015). Nevertheless, incentives are not simply stable factors, influencing many processes in the company. There is a lack of research devoted to incentives taking into account the changing economic and social conditions (Voronov, Lavrinenko and Stashane 2014, pp. 29-30; Kaźmierczyk 2015, p. 87; Romashkina and Andrianova, 2007, p. 50; Wyrwa 2015, p. 127). There is also a lack of in-depth research into motivation factors employed in banks in Poland.

The main aim of this paper is to analyse the diversity of various incentives in banks in Poland among different groups of banks and employees. This paper propounds the following three theses:

- commercial banks use more diverse employee incentives than cooperative ones,

- female employees in banks are motivated less diversely than males,

- managerial staff in banks are motivated more diversely than employees in non-managerial positions.

We used specialist literature in English, Polish and Russian on human resource management, economics, industrial and organizational psychology, and banking (EBSCO, Emerald, BazEkon, ProQuest, The ACM Digital Library). A survey of nearly 2,000 Polish bank employees was also carried out. As the beginning of this article, the meaning of work motivation incentives has been mentioned. It also presents the adopted theses and describes the research method. The further part contains the characterization of the survey sample and the research results.

\section{Employee incentives and theses}

It arouses in the subordinates the feeling of belonging to an organization that takes interest in them and cares for them (Armstrong 1994, p. 66). In practise, a variety of incentives is used to motivate workers. Their range has been expanding over the last 25 years. The increasing diversity of motivational tools resulted not only from the know-how acquired f.ex. from the West but also from the new technologies that facilitated motivation. There are various classifications of employee incentives in the specialist literature. The most popular one postulates a division into wage and non-wage motivators. 
This paper propounds the following three theses:

- commercial banks use more diverse employee incentives than cooperative ones,

- female employees in banks are motivated less diversely than males,

- managerial staff in banks are motivated more diversely than employees in non-managerial positions.

The first thesis is substantiated by the fact that commercial banks possess know-how, which means that they have more knowledge of HR management than cooperative banks (Kaźmierczyk 2011, p. 60). Most commercial banks in Poland have been taken over by foreign capital investors, who provided not only capital but also know-how. In contrast, no cooperative bank in Poland has been taken over by foreign capital. Thanks to the acquired know-how commercial banks are able to manage their workers better and exert more effective influence on their motivation. On the other hand, some studies indicate that the acquisition by foreign capital caused a decline in creativity acquired businesses (Soniewicki 2015, p. 79). Economies of scale are also of importance in this context as some incentives are easier to apply in large organizations such as most commercial banks in Poland. There is a probability that these banks use more employee incentives motivators than cooperative banks. They have the knowledge to do so.

The second thesis which argues that female employees are motivated less diversely than males is based on the main assumptions of the dual labour market theory. In specialist literature, females were classified as one of the groups belonging to the secondary sector ${ }^{\dagger}$ (Kryńska 1997, p. 29; Doeringer and Piore 1970; Reich, Gordon and Edwards 1973; Wachter 1974]. It can be presumed that secondary (worse) sector employees take up worse positions, their employers do not care about their motivation level and therefore do not use many employee incentives.

The third thesis was propounded because the manager plays an important role in strengthening employees' engagement. Managers are responsible for their employees' enthusiasm for work and efficiency. It is their task to understand the factors motivating employees and use them to maximize the efficiency of their subordinates (Pierścieniak, Krenti and Jakieła 2013, p. 45; Kaźmierczyk and Świt 2011, pp. 299-302). For this reason, the manager himself must be a highly motivated person. It ensures his effectiveness in carrying out managerial functions. If managers are adequately motivated, they can influence their non-managerial employees' engagement more effectively. This gives grounds for presuming that managers are motivated more diversely than their subordinates because, from the point of view of an organization, managers' motivation is more important than the motivation of non-managerial employees. A manager with a low level of motivation is not an effective employee and as a result, the whole subordinate team cannot be adequately motivated. Moreover, it is the managers who make decisions concerning the allocation of the limited pool of money that the bank has at its disposal. It is up to them to decide what proportion of money will be allocated for possible bonuses for employees. It may be assumed that they will tend to allocate funds for their own benefit, thus more incentives will be channelled to the managerial staff.

\footnotetext{
$\dagger$ The secondary sector is characterized by lower wages, poorer access to trainings, higher risk of layoffs, less chance of promotion.
} 


\section{Method}

The data from the survey, which was conducted from January 2016 to April 2016, were used to test the research thesis. The "snowball" technique was used in order to collect the data $\$$. The survey participants were invited by existing subjects. Personal contacts and individual visits to banks were used to collect the data. More than 20.000 queries were sent with a request to fill in the questionnaire via e-mail, social networking websites (such as Facebook, GoldenLine and LinkedIn) and thematic forums. Both an electronic version (https://docs.google.com/forms/d/1fq9ZKdr8zXA7zjp8wFowBqJ6ciT4nSmjer598pGWbG0/viewform) and hard copy one of the questionnaire were used in the survey.

The main survey was preceded by a two-staged pilot survey. First, the survey was conducted on a small group of target participants (180 students). The aim was to reveal any inconsistencies and to examine whether the questions were understandable. Thanks to the pilot study, the questionnaire was modified and improved. In the second stage, the target group consisted of 100 employees from the banking sector.

The questionnaires have been completed by 1.949 respondents. 29 questionnaires were rejected due to low credibility and reliability (for example, some respondents selected " 0 " in response to all of the closed-ended questions). As a result, the final research sample consists of 1.920 respondents (152 electronic version and 1768 hard copy). Table 1 provides more details regarding the sample structure.

Table 1. Sample structure

\begin{tabular}{|c|c|c|c|}
\hline \multicolumn{2}{|c|}{ Criterion } & Number of individuals & Percentage \\
\hline \multirow{3}{*}{ Gender } & Female & 1312 & $68.33 \%$ \\
\hline & Male & 473 & $24.64 \%$ \\
\hline & No answer & 135 & $7.03 \%$ \\
\hline \multirow{7}{*}{ Education } & University (major in economics) & 883 & $45.99 \%$ \\
\hline & University (other) & 515 & $26.82 \%$ \\
\hline & High school (major in economics) & 270 & $14.06 \%$ \\
\hline & High school (other) & 189 & $9.84 \%$ \\
\hline & Vocational & 2 & $0.1 \%$ \\
\hline & Elementary & 2 & $0.1 \%$ \\
\hline & No answer & 59 & $3.1 \%$ \\
\hline \multirow{5}{*}{ Occupied position } & Senior managerial position & 43 & $2.24 \%$ \\
\hline & Middle-level managerial position & 129 & $6.72 \%$ \\
\hline & Lower-level managerial position & 153 & $7.97 \%$ \\
\hline & Non-managerial position & 1485 & $77.34 \%$ \\
\hline & No answer & 110 & $5.73 \%$ \\
\hline \multirow{4}{*}{ Organizational unit } & Headquarters & 409 & $21.3 \%$ \\
\hline & Regional branch & 416 & $21.66 \%$ \\
\hline & Operational branch & 1020 & $53.13 \%$ \\
\hline & No answer & 75 & $3.91 \%$ \\
\hline \multirow{2}{*}{ Type of bank } & Commercial bank & 1342 & $69.90 \%$ \\
\hline & Cooperative bank & 481 & $25.05 \%$ \\
\hline
\end{tabular}

\footnotetext{
$\$$ The research results presented are part of a broader study (about: recruitment, forms of employment, motivation, professional education, e-learning, loyalty, stress, work efficiency, MBO, perks, mobbing, professional career, derecruitment, dismissals and outplacement), which was based on the same research method. Thus, the description of the research method is applicable also to the results of research on other aspects of HRM and other papers by Jerzy Kaźmierczyk, e.g. (Aptacy and Kaźmierczyk 2016, pp. 146-158).

$\S$ This method does not generate high research cost. Another advantage is that it allows to reach a wider population and is relatively simple.
} 
The International Journal

ENTREPRENEURSHIP AND SUSTAINABILITY ISSUES

ISSN 2345-0282 (online) http://jssidoi.org/jesi/ 2017 Volume 5 Number 1 (September) http://doi.org/10.9770/jesi.2017.5.1(9)

\begin{tabular}{|c|c|c|c|}
\hline & No answer & 97 & $5.05 \%$ \\
\hline \multirow{3}{*}{ The equity } & National & 919 & $47.86 \%$ \\
\cline { 2 - 4 } & Foreign & 863 & $44.95 \%$ \\
\cline { 2 - 4 } & No answer & 138 & $7.19 \%$ \\
\hline \multirow{3}{*}{ Workplace } & Front office & 1118 & $58.23 \%$ \\
\cline { 2 - 4 } & Back office & 460 & $23.96 \%$ \\
\cline { 2 - 4 } & No answer & 342 & $17.81 \%$ \\
\hline \multirow{3}{*}{ Disability } & Lack & 1820 & $04.79 \%$ \\
\cline { 2 - 4 } & Slight level & 12 & $0.63 \%$ \\
\cline { 2 - 4 } & Moderate level & 2 & $0.1 \%$ \\
\cline { 2 - 4 } & Significant level & 78 & $4.06 \%$ \\
\cline { 2 - 4 } & No answer & 2 & \\
\cline { 2 - 4 } & & & 78 \\
\hline
\end{tabular}

Source: own computations based on the survey data

The composition of the research sample according to gender, type of education and type of bank corresponds to the structure of employment in the banking sector in Poland (Kaźmierczyk 2011, pp. 115-124). The mean age of respondents was 36.612 years. The mean work experience in banking was 12.065 years, ranging from 1 to 43 years. The mean total work experience of respondents was 14.976 years (Table 2).

Table 2. Summary statistics on age and work experience

\begin{tabular}{|c|c|c|c|c|c|}
\hline Criterion & Minimum & Maximum & Mean & Median & Standard deviation \\
\hline Age & 19 & 64 & 36.612 & 35 & 9.7496 \\
\hline Work experience in banking & 1 & 43 & 12.065 & 10.000 & 9.5799 \\
\hline Work experience with current employer & 1 & 43 & 9.835 & 7.000 & 9.3882 \\
\hline Total work experience & 1 & 45 & 14.976 & 12.000 & 10.2416 \\
\hline
\end{tabular}

Source: own computations based on the survey data

The locality size criterion demonstrates that the largest group of respondents came from the localities inhabited by 50 thousand people, the fewest surveyed people coming from localities with 200-500 thousand inhabitants (Table $3)$.

Table 3. Summary statistics on place of residence

\begin{tabular}{|c|c|c|c|}
\hline \multirow{5}{*}{ Size of locality } & to 50 thous people & 658 & $34.27 \%$ \\
\cline { 2 - 3 } & $50-100$ thous people & 251 & $13.07 \%$ \\
\cline { 2 - 3 } & $100-200$ thous people & 245 & $12.76 \%$ \\
\cline { 2 - 3 } & $200-500$ thous people & 124 & $6.46 \%$ \\
\cline { 2 - 3 } & More than 500 thous people & 541 & $28.18 \%$ \\
\cline { 2 - 3 } & No answer & 101 & $5.26 \%$ \\
\hline
\end{tabular}

Source: own computations based on the survey data

The questionnaire consists of an introduction followed by 23 closed-ended questions and several demographic and work-related questions. The main part of the questionnaire contains questions which refer to seven important human resource management areas (recruitment, forms of employment, motivation, professional education, elearning, loyalty, stress, work efficiency, MBO, perks, mobbing, professional career, derecruitment, dismissals and outplacement). Some of the questions were used to test the research thesis. 


\section{Motivating bank employees diversity in light of the empirical research}

The respondents were given a list of motivating factors and asked to mark those that are used at the position they hold. The list of incentives was based on the following sources: (Gick and Tarczyńska 1999, pp. 270-279; Przepiórka 2012; Kopertyńska 2009, pp. 209-215). The incentives are: bonuses, private healthcare, praise, cofinancing of sports and recreation activities, pay rises, holiday subsidy, duty allowance, additional trainings, integration trips, promotions, additional insurance, reprimands, co-financing of education, participation in goal and objective planning, housing assistance, food coupons, co-financing of kindergarten or nursery, subsidized meals and others.

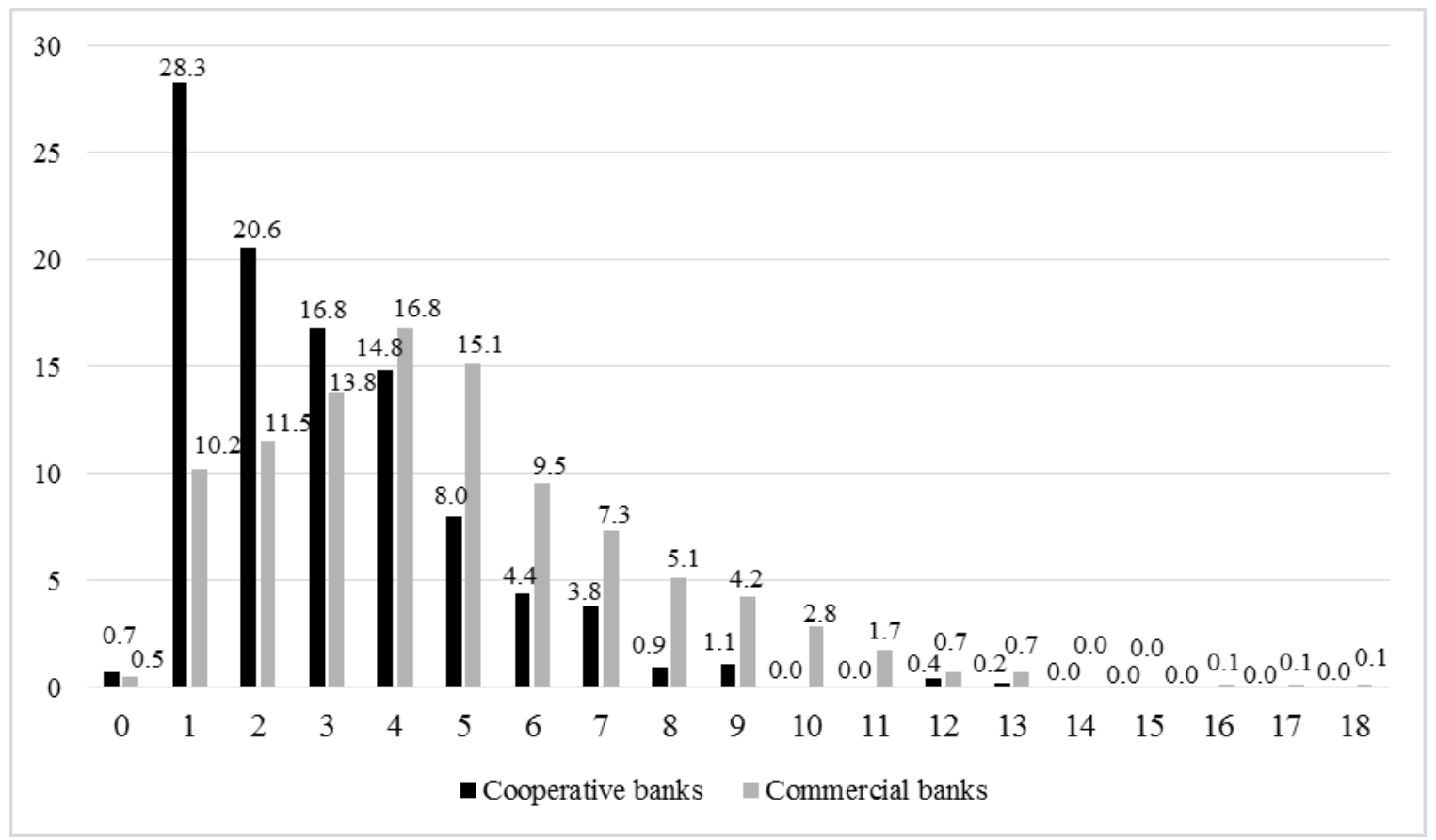

Chart 1. The number of incentives depending on the type of bank (in \%)

Note: The results were obtained at 0.000 significance level, Cramer V $=0.314$, Chi-square $=174.666, \mathrm{df}=16$. Source: own computations based on the survey data

Commercial banks use more diverse employee incentives than cooperative banks (Chart 1), which confirms the first of the propounded theses. The research has shown that the majority of respondents working in cooperative banks are motivated with one incentive. Employees motivated with several incentives constitute a relatively large group, however those motivated with eight or more incentives are rare. As regards the staff of commercial banks, the research results have shown a slightly different tendency: with the increasing diversity of incentives, the number of employees increases and then decreases. Among employees motivated with a number of incentives (more than three), the predominance of commercial bank employees was observed in all of the studied groups. It means that there is a comparatively small group of employees who receive only one or two incentives, in comparison to cooperative banks. 


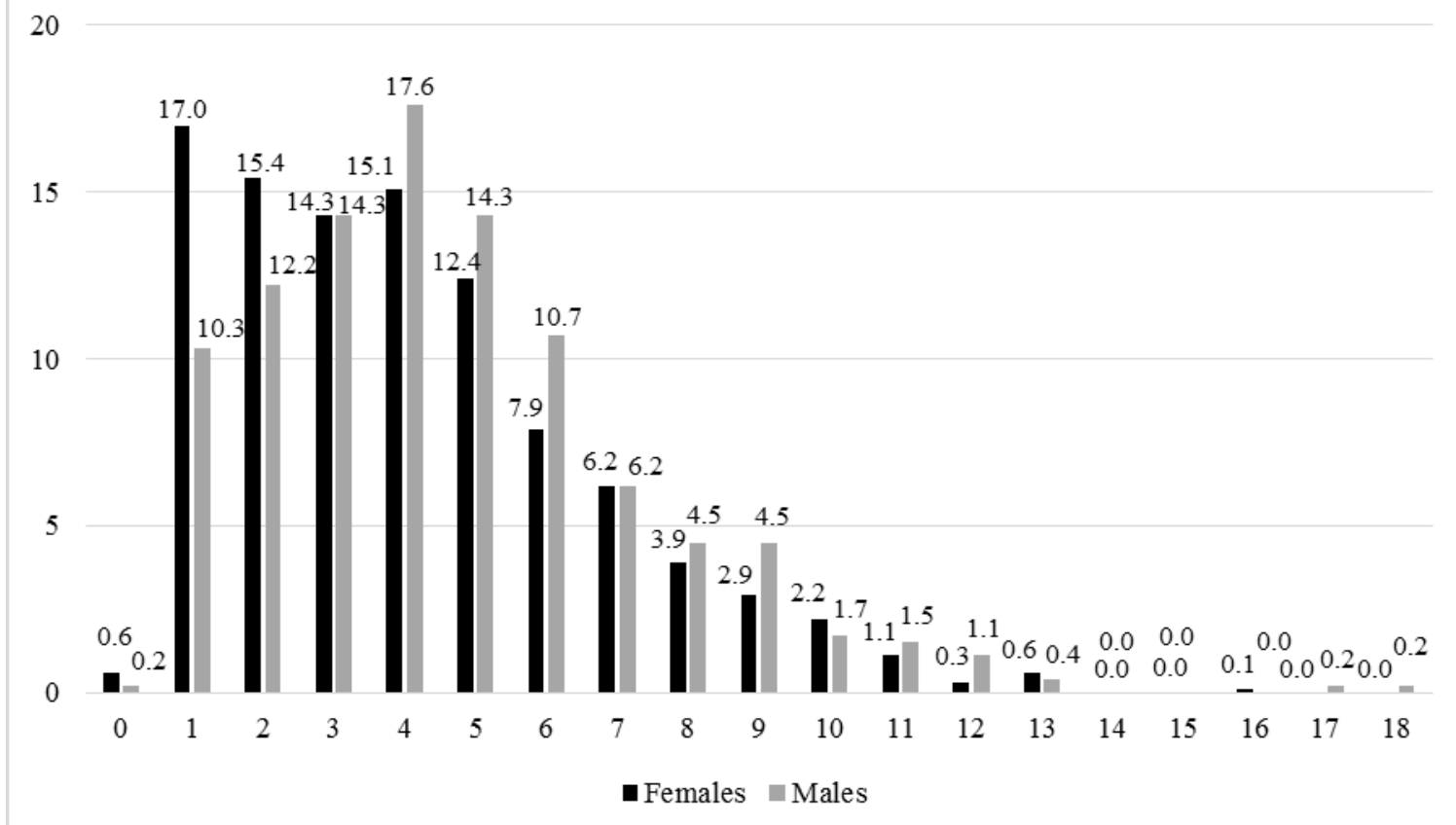

Chart 2. The number of incentives depending on gender (in \%)

Note: The results were obtained at 0.008 significance level, Cramer V =0.137, Chi-square $=32.714, \mathrm{df}=16$.

Source: own computations based on the survey data

The analysis of the research results with reference to the relationship between the number of incentives and the employees' gender of workers, has shown that (Chart 2):

- the most numerous group among female respondents were those receiving only one incentive (17\% of the surveyed females),

- the most numerous group among male respondents were those receiving four incentives $(17.6 \%$ of the surveyed males),

- the more incentives are used in a workplace, the smaller is the percentage of females receiving them,

- with the increasing number of incentives used in a workplace, the number of male employees increases up to a point and then decreases,

- among employees motivated with a number of incentives (more than three), the predominance of male staff was observed in almost all of the studied groups.

These findings confirm the second of the posed theses. Female employees in banks are motivated less diversely than males. 


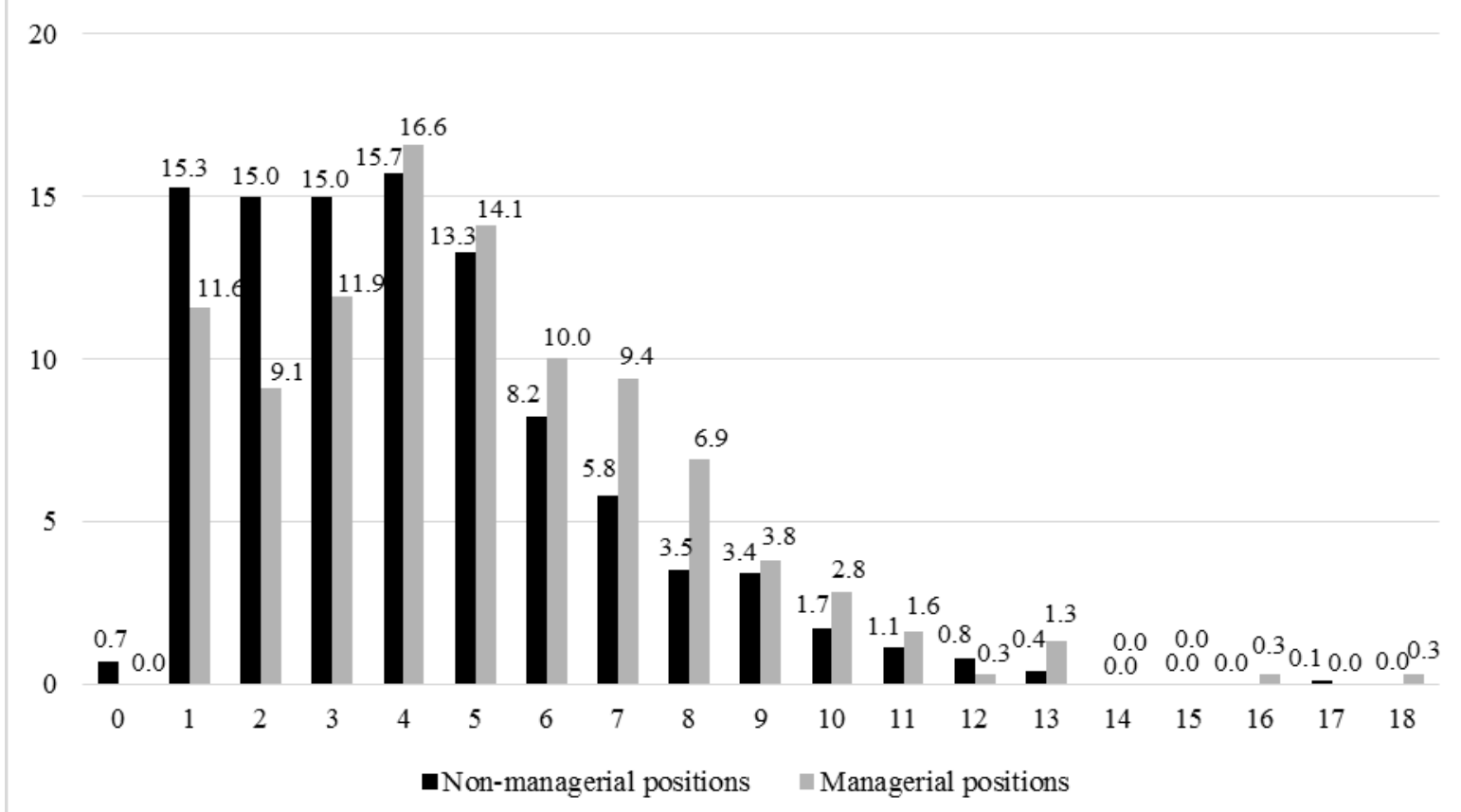

Chart 3. The number of incentives depending on the occupied position (in \%)

Note: The results were obtained at 0,000 significance level, Cramer V = 0.154, Chi-square $=41.969, \mathrm{df}=16$. Source: own computations based on the survey data

The respondents surveyed in this research were divided into two groups: those in managerial and those in nonmanagerial positions. On this basis, the number of incentives used in both groups was examined. The research has shown that in both groups the majority of employees are motivated with four incentives (Chart 3). It also follows from the chart that in the range from 0 to 3 incentives the non-managerial staff are the more numerous group. This testifies to the occurrence of greater disparities between the two studied groups in the range including a larger number of incentives. It has been found that with the rising number of incentives, the number of recipient employees decreases; however, in the range from 4 to 18 incentives, the managerial staff are the more numerous group. In conclusion, the above chart verifies the third thesis. Managerial staff are motivated more diversely than employees in non-managerial positions.

\section{Conclusions}

The empirical research has allowed for the verification of the propounded theses. It has been proved that commercial banks use more diverse employee incentives than cooperative banks. According to the specialist literature, the main reason for this phenomenon lies the fact that commercial banks have the know-how related to conducting banking activities. It includes, among others, the knowledge of personnel management and the understanding of its importance for the efficiency of the entire enterprise, which leads to greater care for the staff and therefore to the use of a larger number of employee incentives.

On the basis of the research results, it has been found that female employees in banks are motivated less diversely than males. The reason for this may be that male employees assume managerial positions more 
The International Journal

ENTREPRENEURSHIP AND SUSTAINABILITY ISSUES

ISSN 2345-0282 (online) http://jssidoi.org/jesi/

2017 Volume 5 Number 1 (September)

http://doi.org/10.9770/jesi.2017.5.1(9)

frequently than females. The examination of the next thesis has shown that employees holding managerial positions are motivated more diversely than those in non-managerial positions.

As regards the thesis concerning the correlation between the occupied position and the diversity of used employee incentives, it has been indicated that this may be due to the managers' greater importance in the organization's hierarchy. It has also been noted that managers play an important role in strengthening the motivation of other employees. The relationship between a manager's level of motivation and the performance of the entire enterprise has been stressed. It has been indicated that another reason for the fact that managerial staff are motivated more diversely may be their management powers and their possible inclination to shape the incentive system for their own benefit.

An analysis presented in this article and research results showed that there is still a big area of banks employees' motivation that should be studied in depth. Certainly the perspective of employers' requires more attention due to the possibility of their different opinion compared with the opinion of employees. The issues that need to be more examined are the causes of the current situation.

\section{Acknowledgement}

The study was sponsored by RGNF (Russian Humanitarian Science Foundation). Project: "Capabilities and Restrictions New Industrialization and Contradictions Sociocultural Space: on Tyumen Region Example", No. 1603-00500. Tyumen State University

\section{References}

Abernethy, M.A.; Dekker, H.C.; Schulz A.K-D. 2015. Are employee selection and incentive contracts complements or substitutes? Journal of Accounting Research 53(4): 633-668. https://doi.org/10.1111/1475-679x.12090

Andrianova, E.V.; Davydenko, V.A. 2011. The character of dynamics of motivation in the Russian Regions, Vestnik Omskovo universiteta, Seriya ekonomika 2: 96-106.

Andrianova, E.V.; Davydenko, V.A.; Romashkina, G.F. 2011. Labour motivation: the social dimension, XII International Scientific Conference, the Problems of Development of Economy and Society, Moscow, 5-7.4.2011, National Research University - Higher School of Economics

Andrianova, E.V.; Romashkina, G.F. 2011. Socio-economic conditionality of labor motives of employees: the example of the various enterprises of the Tyumen region, Vestnik Omskovo universiteta. Seriya ekonomika 1: 104-111.

Aptacy, M.; Kaźmierczyk, J. 2016. The management by objectives in banks: the Polish case, Entrepreneurship and Sustainability Issues 4(2): 146-158. http://dx.doi.org/10.9770/jesi.2016.4.2(3)

Armstrong, M. 1994. Human resource management: strategy and action. London: Kogan Page.

Barska, A., Łuchmus, P. 2007. The importance of a working climate in enterprise image creating. in Bartkowiak, G. (Ed.). HRM in Poland. Chances and threats. Zielona Góra: ZWSHiFM, 39-47.

Burianová, L., Paulík, J. 2014. Corporate social responsibility in commercial banking: a case study from the Czech Republic. Journal of Competitiveness 6(1): 50-70. https://doi.org/10.7441/joc.2014.01.01

Cal-Chrobak, J.; Kaźmierczyk, J. 2017. Qualification A.35. Part 2. Planning and carrying out activities in the organization. Guide to economist vocational training. Helion: Gliwice.

Chernomorchenko, S.I. 2016. Management of organization personal development, Tyumen: Publishing House of Tyumen State University. 
The International Journal

ENTREPRENEURSHIP AND SUSTAINABILITY ISSUES

ISSN 2345-0282 (online) http://jssidoi.org/jesi/

2017 Volume 5 Number 1 (September)

http://doi.org/10.9770/jesi.2017.5.1(9)

Davydenko, V.A. 2004. Specialist model taking into account the professional labor market needs, Specialist Model of the XXI century in the context of the modernization of higher education. Part 1. Materials All-Russia. nauk. method. Conference, September 15-17, Tuapse, $88-92$.

Dirzytė, A.; Rakauskienè, O.G.; Servetkienè, V. 2016. Household income and satisfaction with life: cognitive - emotional impact paradox, Entrepreneurship and Sustainability Issues 4(2): 198-210. http://dx.doi.org/10.9770/jesi.2016.4.2(7)

Doeringer, P.B.; Piore, M.J. 1970. Internal labor markets and manpower analysis. Cambridge: Harvard University, Massachusetts Inst. of Tech.

Drake, A.R.; Wong, J.; Salter, S. 2007. Empowerment, motivation, and performance: examining the impact of feedback and incentives on nonmanagement employees, Behavioral Research in Accounting 19: 71-89.

Erbas, B.C.; Erbas, C. 2004. Employee incentive mechanism design for technology firms, Journal of Integrated Design \& Process Science 8(1): 91-111.

Fulghieri, P.; Sevilir, M. 2011. Mergers, Spinoffs, and Employee Incentives, Review of Financial Studies Vol. 24, Issue 7: $2207-2241$. https://doi.org/10.1093/rfs/hhr004

Gick, A.; Tarczyńska, M. 1999. Employees Motivating. Warsaw: PWE.

Kaźmierczyk, J. 2011. Technological and socio-economic determinants of employment in the banking sector in Poland. Warsaw: CeDeWu.

Kaźmierczyk, J. 2015. Banking Organization and psychology in systemic conditions, in Pietrulewicz, B.; Paszkowicz, M.A. (Ed.). Selected aspects of human activity on the labor market. Zielona Góra: Publishing House of Polish Profesjology Association, p. 87-97.

Kaźmierczyk, J.; Świt, M. 2011. The importance of ethic in the sphere of employment in Polish banking sector, International Conference on Eurasian Economies: 299-305.

Kopertyńska, M.W. 2009. Motivating Employees: Theory and Practice. Warsaw: Placet.

Korauš, A.; Kaščáková, Z.; Parová, V.; Veselovská, S. 2017. Sustainable economic development through human resource management: social intelligence of managers and performance, Journal of Security and Sustainability Issues 6(3): 457477. https://doi.org/10.9770/jssi.2017.6.3(11)

Kryńska, E. 1997. Differentiation of wages and segmentation of the Polish labor market. in Mortimer-Szymczak, H. (Ed.). The Labor Market and Unemployment. Part 4. Lodz: Publishing House of University of Lodz, 27-50.

Ngo, V. M., Nguyen, H. H. 2016. The relationship between Service Quality, Customer Satisfaction nad Customer Loyalty: An Investigations in Vietnamese Retail Banking Sector, Journal of Competitiveness 8(2): 103-116. http://doi.org/10.7441/joc.2016.02.08

Park, R.; Appelbaum, E.; Kruse, D. 2010, Employee involvement and group incentives in manufacturing companies: a multi-level analysis, Human Resource Management Journal 20(3): 227-243. https://doi.org/10.1111/j.1748-8583.2010.00126.x

Pierścieniak, A.; Krent, D.; Jakieła, K. 2013. Intrinsic motivation as a key factor in employee engagement, The Company and Region 5: $38-47$.

Przepiórka, M. 2012. Other than salaries ways to motivate employees. Available on the Internet: http://www.infor.pl/prawo/zarobki/zarobki-w-polsce/300809,Inne-niz-zarobki-sposoby-motywacji-pracownikow.html [4.2.2017]

Rehu, M.; Lusk, E.; Wolff, B. 2005, Incentive preferences of employees in Germany and the USA: An Empirical Investigation, Management Revue 16(1): 81-98. 
The International Journal

ENTREPRENEURSHIP AND SUSTAINABILITY ISSUES

ISSN 2345-0282 (online) http://jssidoi.org/jesi/

2017 Volume 5 Number 1 (September)

http://doi.org/10.9770/jesi.2017.5.1(9)

Reich, M.; Gordon, D.M.; Edwards, R. 1973. Dual labor markets: a theory of lobor market segmentation, Economics Department Faculty Publications, Paper 3, University of Nebraska-Lincoln. Available on the Internet: http://digitalcommons.unl.edu/cgi/viewcontent.cgi?article=1002\&context=econfacpub [1.3.2017].

Romashkina, G.F.; Andrianova E.V. 2007. Job motivation: ideal models and behaviour, Proceedings of the Ural Federal University. Social Sciences 51(3): 50-55.

Rosha, A.; Lace, N. 2015. Sustainable development and behavioural patterns: to innovations through coaching, Journal of Security and Sustainability Issues 5(2): 171-180. https://doi.org/10.9770/jssi.2015.5.2(4)

Soniewicki, M. 2015. The company's international competitive advantage - the role of knowledge. Warszawa: Difin.

Starineca, O.; Voronchuk, I. 2015. Peculiarities of young specialists on labour market: case of Latvia, Entrepreneurship and Sustainability Issues 2(4): 198-208. http://dx.doi.org/10.9770/jesi.2015.2.4(3)

Voronov, V.; Lavrinenko, O.J.; Stashane, J.V. 2014. Assessment of the dynamics of regional disparities (European experience), Sociological studies 1: 29-39.

Wachter, M.L. 1974, Primary and secondary labor markets: a critique of the dual approach, Brooking Papers on Economic Activity 5(3): 637-694. https://doi.org/10.2307/2534250

Wang, H.; Lim, S.S. 2008, Real options and real value: the role of employee incentives to make specific knowledge investments, Strategic Management Journal 29(7): 701-721. https://doi.org/10.1002/smj.681

Wang, H.C.; Barney, J.B. 2006. Employee incentives to make firm-specific investments: implications for resource-based theories of corporate diversification, Academy of Management Review 31(2): 466-476. https://doi.org/10.5465/amr.2006.20208691

Wyrwa, J. 2015. Organizational restructuring as a way of counteracting a crisis in an enterprise, Scientific Journal of Polish Economic Society in Zielona Góra 2: 127-143.

Vladimir Aleksandrovich DAVYDENKO is a Doctor of Science and Professor at Tyumen State University, Head of Research Center (Financial-Economic Institute). Research interests: labour market, HRM, Corporate Culture, trust, economic sociology.

ORCHID Id: http://orcid.org/0000-0001-8389-4254

Jerzy KAŹMIERCZYK $(\mathrm{PhD})$ is a Postdoc at Tyumen State University and Assistant Professor at Poznan University of Economics and Business, Member of the Research Council of Polish Economic Society, Member of the Presidium and Board of Polish Economic Society Zielona Gora and Member of the Regional Labour Market Board at Lubuskie Marshal's Office. He is currently editing an issue of Scientific Journal of Polish Economic Society in Zielona Gora. Research interests: labour market, HRM, banking, macroeconomics.

ORCHID Id: orcid.org/0000-0002-5976-0210

Gulnara Fatykhovna ROMASHKINA is a Doctor of Science and Professor at Tyumen State University, Research interests: labour market, HRM, economic sociology.

ORCHID Id: http://orcid.org/0000-0002-7764-5566

Elżbieta ŻELICHOWSKA is a graduate of Poznan University of Economics and Business and practitioner of HRM. Research interests: Work motivation, Human Resources Management, labour market.

ORCHID Id: http://orcid.org/0000-0002-1642-9181

Copyright (C) 2017 by author(s) and VsI Entrepreneurship and Sustainability Center

This work is licensed under the Creative Commons Attribution International License (CC BY).

http://creativecommons.org/licenses/by/4.0/

(c) (†) Open Access 